\begin{tabular}{c}
$\begin{array}{c}\text { Advances in Research } \\
\text { Advances in } \\
\text { Research }\end{array}$ \\
3(4): 404-416, 2015, Article no.AIR.2015.036 \\
ISSN: 2348-0394 \\
SCIENCEDOMAIN international \\
www.SCiencedomain.org \\
\hline
\end{tabular}

\title{
Assessing Respiratory Inflammation among Children Living Near to Non-sanitary Landfill Using Interleukin-6 (IL-6)
}

\author{
Sharifah Norkhadijah S. Ismail ${ }^{{ }^{\star}}$, Muhammad S. Othman ${ }^{1}$, Dora E. Jamaluddin ${ }^{1}$, \\ Sarva M. Praveena ${ }^{1}$, Ho Y. Bin ${ }^{1}$, Emilia Z. Abidin', Aini Syuhaida A. Wahab ${ }^{1}$ \\ and A. Haryati ${ }^{2}$ \\ ${ }^{1}$ Department of Environmental and Occupational Health, Faculty of Medicine and Health Sciences, \\ University Putra Malaysia, 43400 Serdang, Malaysia. \\ ${ }^{2}$ Department of Pharmaceutical Biology, Faculty of Pharmaceutical Sciences, UCSI University, 56000 \\ Kuala Lumpur, Malaysia.
}

Authors' contributions

This work was carried out in collaboration between all authors. Author SNSI designed the study, wrote the protocol, and wrote the first draft of the manuscript. Authors MSO and DEJ managed the literature searches and sample collection and performed the experimental process. Authors SMP, $H Y B, E Z A$ and $A H$ managed the editorial process of the manuscript and data analysis. All authors read and approved the final manuscript.

Article Information

DOI: 10.9734/AIR/2015/14478 Editor(s):

(1) Claudia Borza, "Victor Babes" University of Medicine and Pharmacy, Department of Pathophysiology, România.

(1) Gülsen Meral Sezer, Kagithane State Hospital, Specialty in Pediatrics, Istanbul, 344 $\frac{\text { Reviewers: }}{15 \text {, Turkey }}$ (2) Ron Mathison, Physiology and Pharmacology, University of Calgary, Canada. Complete Peer review History: http://www.sciencedomain.org/review-history.php?iid=756\&id=31\&aid=6986

Original Research Article

Received $30^{\text {th }}$ September 2014

Accepted $3^{\text {rd }}$ November 2014

Published $18^{\text {th }}$ November 2014

\section{ABSTRACT}

Aims: To determine the respiratory inflammation among children living near to non-sanitary municipal solid waste landfill area and the concentration of Interleukin-6 cytokine.

Study Design: A cross-sectional comparative study design.

Place and Duration of Study: Sample: Pajam, Negeri Sembilan, Malaysia, between September 2013 and April 2014.

Methodology: A total of 72 children were randomly selected based on the inclusive and exclusive criteria. A set of pre-tested questionnaires were utilized to obtain socio-demographic information and to predict health risk faced by the respondents. Saliva samples of the respondents were collected 
and analyzed using Human Interleukin-6 (IL-6) Platinum ELISA (Enzyme-Linked Immunosorbent Assay) kit.

Results: The $\mathrm{PM}_{10}$ concentration for the exposed group was higher than the unexposed group with the mean \pm standard deviation (SD) of $152.31 \pm 31.07 \mu \mathrm{g} / \mathrm{m}^{3}$ and $87.77 \pm 30.77 \mu \mathrm{g} / \mathrm{m}^{3}$ respectively. The mean $\pm S D$ of the Interleukin- 6 for the exposed group was slightly higher than the unexposed group with the mean $\pm \mathrm{SD}$ of $6.34 \pm 1.95 \mathrm{pg} / \mathrm{ml}$ and $5.77 \pm 1.08 \mathrm{pg} / \mathrm{ml}$ respectively. The most common symptoms reported was sneezing and sore throat. There was no significant correlation between PM10 concentration and IL-6 in this study.

Conclusion: The findings exhibit that there was no association between Interleukin- 6 and $\mathrm{PM}_{10}$ concentration of the respondent. However, there are likely potential adverse health impacts arising from particulates exposure among exposed children in this study. Respondents are advised to have a medical check-up in order to determine respiratory health status thus elimination the risks of acquiring respiratory inflammation.

Keywords: Respiratory inflammation; children; landfill; saliva; Interleukin-6.

\section{INTRODUCTION}

Landfilling is the most frequent municipal solid waste (MSW) disposal method worldwide, recognized especially in low- and middle-income countries [1]. Approximately 338 million tonnes of waste were landfilled in poor operated landfills and 71.5 million tonnes waste were disposed through open dumpingin low- and middle-income countries [2].

Most landfills in the country are in a worse condition [3], that were operated without proper protective measures, such as lining systems, leachate treatment and gas venting. As a country that ismoving forward to achieve the industrialized country status by the year 2020, Malaysia cannot escape from facing the solid waste management problems [4] and most of landfills are located near to the residence area. There are 230 landfills reported in Malaysia and the majority of them are crude dumping ground. Landfill causes natural resource pollution and various environmental problems such as health hazards, surface water and ground water contamination, odors and many more [4].

Municipal Solid Waste (MSW) is defined as trash or garbage which consists of everday items that were used and thrown away, such as packaging product, furniture, bottles, newspaper, plastics, clothing and food scraps [5]. Landfill sites such as hazardous landfill have been investigated as the possible cause of birth defects, cancers and respiratory illnesses including asthma. A study in the United Kingdom has recently identified a link between living within $2 \mathrm{~km}$ from a landfill site and a small increased risk of birth defects [6]. Symptoms such as tiredness, sleepiness and headaches have also had been reported.
Landfilling activities also have the potential to produce both fine and coarse particulates, the make-up of which will depend on the activities undertaken on-site and the types of waste being handled. It is also has with the potential to generate particulates through movement of waste on- and off-site, plant traffic both on- and off-site and dust generated from the surface of the landfill [7]. Exposure to particles that can enter the respiratory system is known to be associated with a range of adverse effect on health. For instance, particulate matter with small diameter, such as $\mathrm{PM}_{2.5}$ is likely to penetrate beyond the nose and larynx and the likelihood of their entering lungs and being deposited in the airways increased [7].

A study found that living near a landfill could expose residents to chemicals that can reduce immune system function and lead to an increased risk of infections [8]. As opposed to children living in clean areas, the study found that children living near to waste sites, whether landfills or contaminated bodies of water, are hospitalized more frequently with acute respiratory infections. Children living near to waste sites also had increased rates of asthma [9]. Long-term exposures, such as those experienced by people living for many years in areas with high particle levels, have been associated with problems such as reduced lung function and the development of chronic bronchitis and even premature death. Short-term exposures refers to particles (hours or days) can aggravate lung disease, causing asthma attacks and acute bronchitis, and may also increase susceptibility to respiratory infections [7]. Children are more vulnerable to their environments than adults, and for this reason 
they are most sensitive to the pollution. The respiratory system is one of the prime organ systems most exposed to the effects of the environment [10].

Interleukin-6 (IL-6) is a pleiotropic cytokine involved in a multitude of inflammatory responses with roles in immune regulation and pathologic conditions including both acute and chronic inflammatory diseases IL-6 initiates and up-regulates inflammation, triggers the release of acute phase proteins, regulates inflammatory response, attracts immune cells to sites of injury or infection and stimulates coagulation [11]. Salivary levels have varying correlations to serum levels depending on the research applications [12].

No research has assessed respiratory problems associated to distance from MSW landfill using the inflammatory cytokine IL-6. The objective of this study was to determine the respiratory inflammation among the exposed children (i.e. within $2 \mathrm{~km}$ radius from landfill) and unexposed children (i.e. more than $2 \mathrm{~km}$ radius from landfill) using IL-6 as the bio-indicator to the presence the inflammation. This research also was carried out to determine the inhalation exposure of $\mathrm{PM}_{10}$ among exposed and unexposed children and to determine the relationship between IL-6 concentration and $\mathrm{PM}_{10}$ concentration towards associated respiratory health symptoms. This study provides basic information on respiratory inflammation using IL-6 and the risk of respiratory problem from living near to municipal landfill.

\section{MATERIALS AND METHODS}

\subsection{Study Design}

A cross-sectional comparative study design was used to determine the respiratory inflammation among children living near to the MSW landfill area. This kind of study is selected as it is relatively simple and economical to be conducted. It is also useful for investigating exposure that is already has fixed characteristics.

This study was conducted at residential area near a non-sanitary landfill Level 2 in Pajam, Negeri Sembilan, Malaysia. This study location is selected due to presence of MSW landfill in that area-where it is located within the residential area. In this study, exposed group was children who lives within $2 \mathrm{~km}$ radius from the landfill sites while for the unexposed group was the children who lives more than $2 \mathrm{~km}$ radius from the landfill.

\subsection{Area Description and Study Population}

Fig. 1 shows the study location which is in Pajam-Nilai, one of the developing districts in Negeri Sembilan, Malaysia. Negeri Sembilan is mainly an agricultural state. However, the establishment of several industrial estates in this area has enhanced the manufacturing sector as a major contributor towards the state economy. Development projects can be seen as one drives towards the urbanization of this area. Due to its proximity, and connection through the railways system to Kuala Lumpur, Putrajaya, and Kuala Lumpur International Airport (KLIA), PajamNilaiis a rapidly growing town. Pajam-Nilai was selected as study location due to the existence of non-sanitary landfill which is in within $2 \mathrm{~km}$ radius from the residence area. Residence areas involved in this study are $\mathrm{Kg}$. Gebok, Taman Anggrik Pajam, Batang Benar, Taman Bukit Inai, Taman Melor and Taman Dahlia. The residence area more than $2 \mathrm{~km}$ radius away from landfill site, are Taman Semarak, Taman Desa Jasmine, Taman Desa Cempaka, Taman Nilai Perdana, Taman Desa Indah and Taman Melati.

\subsection{Data Collection}

\subsubsection{Questionnaire}

The questionnaire used in this study takes into account on previous findings from literature and was adapted from American Thoracic Society's Recommended Respiratory Disease Questionnaires in identifying risk factors and population at risk from particulates exposure as well as health risk arising from particulates exposure [13]. The respondent's parent filled in the self-administrated questionnaire. The questionnaire elicits information on personal and socio-demographic information, environmental risk factors, health status and other relevant factors. The following information is elicited in the questionnaire:

Section A: Socio-demographic Section B:Information on respondents' respiration status

Section C: Respondent's allergic information

Section D: Smoking behavior 


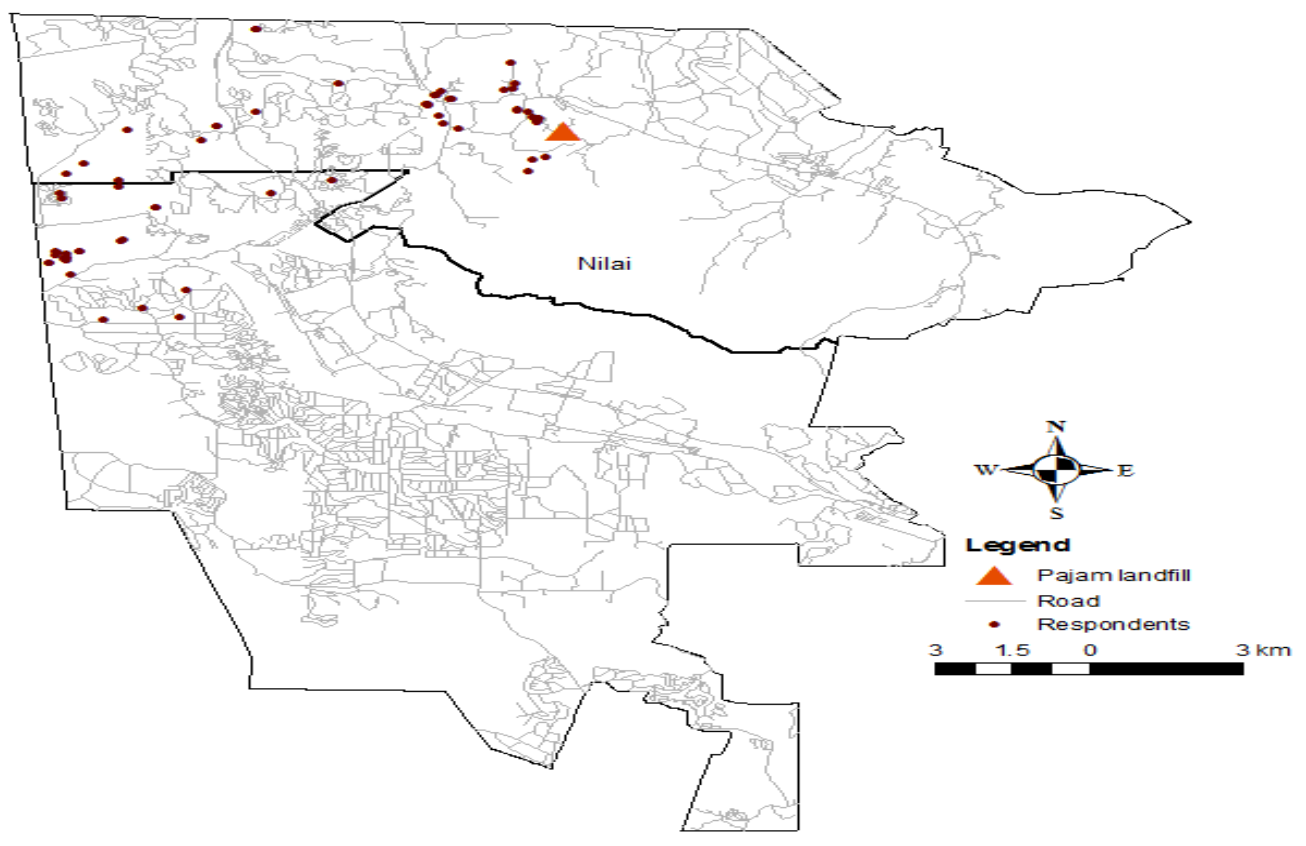

Fig. 1. Study location, Pajam-Nilai

\subsubsection{Salivary interleukin- 6 sampling}

Respondents' saliva were collected using unstimulated passive drool technique in order to maintain consistency in the type of saliva sample collected. Whole saliva was collected by tilting the head forward, allowing the saliva to pool on the floor of the mouth and then passed through the Saliva Collection Aid (SCA). To avoid the possibility of contaminating saliva with substances that could interfere with the immunoassay, some precautions were taken. Respondents were asked to avoid major meals within 60 minutes of sample collection as saliva collection was made in the early of the morning. Respondents also rinsed their mouth with plain water to remove food residue before sample collection. In order to avoid sample dilution, saliva was collected after 10 minutes of rinsing. Once saliva collected and passed through Saliva Collection Aid (SCA), sample were temporarily stored and maintained at $4^{\circ} \mathrm{C}$ within 2 hours before storedat $-20^{\circ} \mathrm{C}$ to protect unstable analytes and to prevent bacterial growth.

\subsubsection{Personal air sampling}

The purpose of personal air monitoring was to determine an individual's exposure to particulate matter. Personal air monitoring was done for 8 hours and the average concentration of particulate matter was taken as the result. The air-sampling pump with cyclone was placed on the respondent within his/her breathing zone, by clipping the monitor to the shirt collar. Every 1 hour, the position and condition of the equipment was checked. This was to ensure that the hose has not become pinched or detached from the cassette or the pump. After 8 hours, the pumps was turn off and remove from the respondents. For the blank field sample, one blank prepared by leaving it at the field but not used to take samples.

\subsection{Sample Analysis}

Saliva samples were analyzed by using Human IL-6 Platinum ELISA, an enzyme-linked immunosorbent assay for the quantitative detection of human IL-6.Saliva samples were analyzed by referring to the product information and manual from the kit's provider. Once the number of microwell strips required to test the desired number of sample is determined, each of the samples including also the blank, standard were assayed in duplicate. All microwell strips were washed twice using approximately $400 \mu \mathrm{l}$ of Wash Buffer per well. Next, standard dilution on microwell plate is prepared. Then, $100 \mu \mathrm{l}$ of Assay Buffer (1x) was added in duplicate to blank well while $50 \mu \mathrm{l}$ of Assay Buffer (1x) was added to the sample wells. Next, $50 \mu \mathrm{l}$ of each sample was added in duplicate to the sample 
wells. $50 \mu$ of Bioting-Conjugate was added to all wells and left for 2 hours for incubation at room temperature. Once incubation process done, 100 $\mu \mathrm{l}$ of dilured Streptavidin-HRP was added to all wells, including the blank well and left for 1 hour for incubation at room temperature $\left(18-25^{\circ} \mathrm{C}\right)$. $100 \mu \mathrm{l}$ TMB Substrate was pipetted to all wells and the plates were incubated again at room temperature for $10 \mathrm{~min}$. After 10 minutes, the colour development on the plate should be monitored and the substrate reaction stopped. $100 \mu \mathrm{l}$ of Stop solution was added when highest standard had developed a dark blue colour to stop the enzyme reaction. Absorbances of each microwell were read on a pectro-photometer using $450 \mathrm{~nm}$ as the primary wave length.

\subsection{Data Analysis}

Descriptive statistics were used to analyze the socio-demographic information of the respondent, respondent health-related problems, and other possible exposure which lead to respiration inflammation. Compare mean test was performed to determine the difference of data between groups of respondents. A correlation test was performed to determine the relationship between concentration of Interleukin6 in saliva and health related problem.

\section{RESULTS AND DISCUSSION}

\subsection{Socio-demographic Information of Respondent}

Study respondents were recruited from area Pajam; for exposed group and unexposed group. Respondent consists of 32 boys (44.4\%) and 40 girls $(56.3 \%)$. The majority of the respondents are Malay (95.8\%) and $4.2 \%$ of them are Indian (Table 1). All respondents aged between 7 to 12 years old are presently studying in primary school. The majority of the respondent's parent from the exposed group have educational background of diploma level $(\mathrm{N}=16)$ while the majority of the parent from the unexposed group have educational background of upper secondary level $(\mathrm{N}=16)$. In terms of family income, most of the parents in both groups were in high income category group which is more than RM 2,000 per month (i.e. $\mathrm{N}=32$ for exposed and $\mathrm{N}=29$ for unexposed). Only one family $(\mathrm{N}=1)$ in the unexposed group was in the poor category of family income. The compare mean test indicate there was significant differences for gender $p$-value $=0.036$ and age $p$-value $<0.001$ between exposed and unexposed groups.
The average duration of residence was 9 years $(8.69 \pm 6.28$ years for exposed and $9.14 \pm 3.73$ for unexposed). The majority of the families for both groups had lived in that area for 6 to 10 years $(\mathrm{N}=14$ for exposed and $\mathrm{N}=17$ for the unexposed). Twelve $(\mathrm{N}=12)$ families in exposed group had lived in the area for 1 to 5 years and only 9 families had lived more than 10 years in the particular area. For the unexposed group, 12 families had lived in the area more than 10 years while only 8 families had lived for less than 5 years. No significant differences was detected for residence duration between exposed and unexposed groups with $p$-value $=0.711$.

A small number of children in exposed group ( $\mathrm{N}$ = 6) and 17 children in the unexposed group, were living with pets, with no significant difference between the two groups. Having pets has been identified as risk factors to respiratory inflammation. $25 \%$ of people with health related problems live with their pets [14].

Among the fathers of the exposed children in this study, eight $(\mathrm{N}=8)$ of them are regular smokers, 5 of them are social smokers and 22 of them are non-smoker. While among fathers of the unexposed children, 8 of them are smoker, 10 of them are social smoker and 19 of them are nonsmoker. Among the mothers of the exposed children, all of them $(\mathrm{N}=35)$ are non smokers while in unexposed children, 3 of them are social smoker. As for other smoking family members who are living together with the children, only 1 of them is in exposed group while 5 of them in unexposed group are smokers. There were no significant differences between exposed and unexposed group of smoking behavior among family members.

\subsection{Inhalation Exposure of $\mathrm{PM}_{10}$ and IL-6 Concentration}

Table 2 shows the mean \pm SD of $\mathrm{PM}_{10}$ inhaled by exposed and unexposed group for 8-hours monitoring. The mean \pm SD of $\mathrm{PM}_{10}$ for exposed children was $152.31 \pm 31.07 \mu \mathrm{\mu g} / \mathrm{m}^{3}$ and $87.77 \pm 30.77 \mu \mathrm{g} / \mathrm{m}^{3}$ for the unexposed children. The mean \pm SD of $\mathrm{PM}_{10}$ for exposed children was slightly higher compared to the Recommended Malaysian Air Quality Guideline (RMAQG) for $\mathrm{PM}_{10}$ by the Department of Environment Malaysia, which is $150 \mu \mathrm{g} / \mathrm{m}^{3}$ for 24 hours monitoring. There was a significant difference of inhalation exposure to $\mathrm{PM}_{10}$ between exposed and the unexposed group in this study $(p<0.001)$. 
Table 1. Demographic, socioeconomic distribution and lifestyle of respondents

\begin{tabular}{|c|c|c|c|}
\hline \multirow[t]{2}{*}{ Variable } & \multirow{2}{*}{$\begin{array}{l}\text { Exposed group }^{\mathrm{a}}(\mathrm{N}=35) \\
\mathrm{N}(\%)\end{array}$} & \multirow{2}{*}{$\begin{array}{l}\text { Unexposed group }^{\mathrm{b}}(\mathrm{N}=37) \\
\mathrm{N}(\%)\end{array}$} & \multirow[t]{2}{*}{$p$-value } \\
\hline & & & \\
\hline Gender & & & $.036^{\star}$ \\
\hline Boys & $20(57.1)$ & $12(67.56)$ & \\
\hline Girls & $15(42.9)$ & $25(32.44)$ & \\
\hline Ethnicity & & & .071 \\
\hline Malay & $32(91.43)$ & $35(100)$ & \\
\hline Indian & $3(8.57)$ & $0(0.0)$ & \\
\hline Religion & & & .071 \\
\hline Islam & $32(91.43)$ & $35(100)$ & \\
\hline Hindu & $3(8.57)$ & $0(0.0)$ & \\
\hline Age (years) & & & $<.001^{*}$ \\
\hline 8 & $1(2.9)$ & $2(5.5)$ & \\
\hline 10 & $29(82.8)$ & $3(8.1)$ & \\
\hline 11 & $4(11.4)$ & $9(24.3)$ & \\
\hline 12 & $1(2.9)$ & $23(62.1)$ & \\
\hline Parental education & & & .986 \\
\hline Lower secondary level & $1(2.9)$ & $2(5.4)$ & \\
\hline Upper secondary level & $11(31.4)$ & $14(37.8)$ & \\
\hline Diploma & $16(45.7)$ & $10(27.0)$ & \\
\hline University & $7(20.0)$ & $11(29.7)$ & \\
\hline Masters & $0(0.0)$ & $3(8.1)$ & \\
\hline Family income (RM) :** & & & .599 \\
\hline Poor & $0(0.0)$ & $1(2.7)$ & \\
\hline Intermediate & $3(4.6)$ & $7(18.9)$ & \\
\hline High & $32(91.4)$ & $29(78.4)$ & \\
\hline \multicolumn{4}{|l|}{ Years of residence } \\
\hline 1 to 5 & $12(34.3)$ & $8(21.6)$ & 0.711 \\
\hline 6 to 10 & $14(40.0)$ & $17(45.9)$ & \\
\hline$>10$ & $9(25.7)$ & $12(32.4)$ & \\
\hline \multicolumn{4}{|l|}{ Pet } \\
\hline Yes & $6(17.1)$ & $17(45.9)$ & .148 \\
\hline No & $29(82.9)$ & $20(54.1)$ & \\
\hline \multicolumn{4}{|l|}{ Smoking father } \\
\hline Regular smoker & $8(22.9)$ & $8(21.6)$ & .900 \\
\hline Non-smoker & $22(62.9)$ & $19(51.4)$ & \\
\hline Social smoker & $5(14.2)$ & $10(27.0)$ & .183 \\
\hline $\begin{array}{l}\text { Smoking mother } \\
\text { Regular smoker }\end{array}$ & $0(0)$ & $0(0)$ & .145 \\
\hline Non-smoker & $35(100)$ & $34(91.9)$ & \\
\hline \multirow{2}{*}{\multicolumn{4}{|c|}{ Other family members }} \\
\hline & & & \\
\hline Smoker & $1(2.9)$ & $5(14.3)$ & .102 \\
\hline Non-smoker & $34(97.1)$ & $32(85.7)$ & \\
\hline
\end{tabular}

The mean \pm SD of IL- 6 was $6.34 \pm 1.95 \mathrm{pg} / \mathrm{mlfor}$ exposed children and $5.77 \pm 1.08 \mathrm{pg} / \mathrm{ml}$ for the unexposed group. The mean \pm SD IL- 6 for boys in the exposed group was $6.38 \pm 1.81 \mathrm{pg} / \mathrm{ml}$ and $6.29 \pm 2.18 \mathrm{pg} / \mathrm{ml}$ for girls. The IL-6 concentration for boys in unexposed group was $5.89 \pm 1.14$ $\mathrm{pg} / \mathrm{mland} 5.72 \pm 1.06 \mathrm{pg} / \mathrm{ml}$ for girls. The Mann Whitney-U test indicates that there was no significant difference observed between IL-6 concentration in saliva of exposed and unexposed group ( $p>0.05$ ). 
A positive relationship was determined between IL-6 and $\mathrm{PM}_{10}$ although it was not significant $(R=0.49, p=0.684)$.

\subsection{Respiratory Health Symptoms}

Table 3 shows the health symptoms reported among boys and girls. The highest symptoms reported for the exposed group was sneezing $(\mathrm{N}=11)$ and sore throat $(\mathrm{N}=7)$ followed by wheezing with flu $(\mathrm{N}=4)$, runny nose $(\mathrm{N}=4)$, watery eyes $(\mathrm{N}=4)$ and sinus $(\mathrm{N}=4)$. Less symptoms were reported among respondents in the exposed group for wheezing during daytime $(\mathrm{N}=3)$, wheezing during night $(\mathrm{N}=1)$ and coughing with phlegm $(\mathrm{N}=1)$. Meanwhile, the highest symptoms reported among unexposed children were sneezing $(\mathrm{N}=10)$ and sinus $(\mathrm{N}=6)$. Other symptoms also were reported among unexposed group such as wheezing with flu $(\mathrm{N}=1)$ and wheezing after doing sports $(\mathrm{N}=1)$. However, there was no significant difference of having the respiratory symptoms between boys and girls among the exposed and unexposed children. There were significant differences for the symptoms of watery eyes ( $p$-value $=0.003$ ), coughing with phlegm ( $p$-value $=0.003)$ and sore throat ( $p$-value $=0.003$ ) between groups.

Table 4 shows the frequency of lung inflammation symptoms among respondents. The majority of the children in exposed group never suffered coughing without flu $(\mathrm{N}=21)$ and asphyxiate (coughing and flu) ( $\mathrm{N}=27)$. Most of the children in this group have experienced symptoms of coughing with flu ( $\mathrm{N}=17)$, coughing without flu $(\mathrm{N}=8)$, asphyxiate (coughing without flu) $(\mathrm{N}=17)$ once in a week and symptom of asphyxiate (coughing without flu) $(\mathrm{N}=11)$ once in a month. A small of number of children have experienced symptoms of coughing with flu $(\mathrm{N}=2)$, coughing without flu $(\mathrm{N}=1)$ and asphyxiate (coughing without flu) $(\mathrm{N}=1)$ almost every day in their life.

Table 2. PM 10 and IL-6 concentration of exposed and unexposed children

\begin{tabular}{llll}
\hline Variable & Exposed group $^{\mathrm{a}}(\mathrm{N}=35)$ & Unexposed group ${ }^{\mathrm{b}}(\mathrm{N}=37)$ & $p$-value \\
\cline { 2 - 4 } & Mean $\pm \mathrm{SD}$ & Mean $\pm \mathrm{SD}$ & $<0.001^{*}$ \\
\hline $\mathrm{PM}^{10}$ concentration $\left(\mu \mathrm{gg} / \mathrm{m}^{3}\right)$ & $152.31 \pm 31.07$ & $87.77 \pm 30.77$ & \\
$\mathrm{IL} 6$ concentration $(\mathrm{pg} / \mathrm{ml})$ & & & 0.450 \\
Boys & $6.38 \pm 1.81$ & $5.89 \pm 1.14$ & \\
Girls & $6.29 \pm 2.18$ & $5.79 \pm 1.06$ & \\
Total & $6.34 \pm 1.95$ & $5.77 \pm 1.08$ & \\
\hline \multicolumn{4}{c}{$N=72,{ }^{a}$ reside less than $2 \mathrm{~km}$ from landfill, ${ }^{\circ}$ reside more than $2 \mathrm{~km}$ from landfill, ${ }^{*} z=-6.128$}
\end{tabular}

Table 3. Distribution data for other respiratory health symptoms among studied children

\begin{tabular}{|c|c|c|c|c|c|c|}
\hline \multirow[t]{2}{*}{ Symptoms } & \multicolumn{2}{|c|}{$\begin{array}{c}\text { Exposed group }^{a} \\
(\mathrm{~N}=35)\end{array}$} & \multicolumn{2}{|c|}{$\begin{array}{l}\text { Unexposed group } \\
(\mathrm{N}=37)\end{array}$} & \multirow[t]{2}{*}{$x^{2}$ value $^{1}$} & \multirow[t]{2}{*}{ P value } \\
\hline & $\begin{array}{l}\text { Boys } \\
\text { N (\%) }\end{array}$ & $\begin{array}{l}\text { Girls } \\
\text { N (\%) }\end{array}$ & $\begin{array}{l}\text { Boys } \\
\text { N (\%) }\end{array}$ & $\begin{array}{l}\text { Girls } \\
\text { N (\%) }\end{array}$ & & \\
\hline Wheezing with flu & $3(15.0)$ & $1(6.7)$ & $1(8.3)$ & $0(0.0)$ & 2.119 & .145 \\
\hline Wheezing during day time & $1(5.0)$ & $2(13.3)$ & $0(0.0)$ & $0(0.0)$ & 1.072 & .300 \\
\hline Wheezing during night & $1(5.0)$ & $0(0.0)$ & $0(0.0)$ & $0(0.0)$ & 3.309 & .069 \\
\hline Wheezing after sports & $0(0.0)$ & $0(0.0)$ & $1(8.3)$ & $0(0.0)$ & .986 & .321 \\
\hline Runny nose & $3(5.0)$ & $1(6.7)$ & $0(0.0)$ & $3(12.0)$ & .270 & .874 \\
\hline Sneezing & $4(20.0)$ & $7(46.7)$ & $2(16.7)$ & $8(32.0)$ & .342 & .843 \\
\hline Watery eyes & $2(10.0)$ & 2 (13.3) & $0(0.0)$ & $0(0.0)$ & 11.580 & $.003^{*}$ \\
\hline Coughing with phlegm & $1(5.0)$ & $0(0.0)$ & $0(0.0)$ & $0(0.0)$ & 11.679 & $.003^{*}$ \\
\hline Sore throat & $5(25.0)$ & $2(13.3)$ & $0(0.0)$ & $0(0.0)$ & 16.238 & $<.001^{*}$ \\
\hline Sinus & $2(10.0)$ & $2(13.3)$ & $2(16.7)$ & $4(16.0)$ & .191 & .662 \\
\hline
\end{tabular}


Table 4. The descriptive statistics of the potential symptoms of lung inflammation exposure among exposed and unexposed group with the mann whitney-U test $(p=0.05)$

\begin{tabular}{|c|c|c|c|c|c|c|c|c|c|c|}
\hline \multirow[t]{2}{*}{ Symptoms } & \multicolumn{5}{|c|}{ Exposed group $^{\mathrm{a}}(\mathrm{N}=35)$} & \multicolumn{5}{|c|}{ Unexposed group $^{\mathrm{b}}(\mathrm{N}=37)$} \\
\hline & Everyday & $\begin{array}{l}\text { Once in } \\
\text { a week }\end{array}$ & $\begin{array}{l}\text { Once in } \\
\text { a month }\end{array}$ & $\begin{array}{l}\text { Once or twice } \\
\text { in a year }\end{array}$ & Never & Everyday & $\begin{array}{l}\text { Once in } \\
\text { a week }\end{array}$ & $\begin{array}{l}\text { Once in a } \\
\text { month }\end{array}$ & $\begin{array}{l}\text { Once or twice } \\
\text { in a year }\end{array}$ & Never \\
\hline Coughing with flu & $2(5.71)$ & $17(48.6)$ & $4(11.4)$ & $3(8.57)$ & 9 (25.7) & $2(5.4)$ & $14(37.8)$ & $7(18.9)$ & $11(29.7)$ & $3(8.1)$ \\
\hline Coughing without flu & $1(2.8)$ & $8(22.8)$ & $4(11.4)$ & $1(2.8)$ & $21(60)$ & $1(2.7)$ & $5(13.5)$ & $4(10.8)$ & $5(13.5)$ & $22(59.4)$ \\
\hline $\begin{array}{l}\text { Asphyxiate } \\
\text { (coughing and flu) }\end{array}$ & $0(0.0)$ & $2(5.71)$ & $2(5.71)$ & $4(11.4)$ & $27(77.1)$ & $0(0.0)$ & $3(8.1)$ & $2(5.4)$ & $5(13.5)$ & $27(72.9)$ \\
\hline $\begin{array}{l}\text { Asphyxiate (coughing } \\
\text { but without flu) }\end{array}$ & $1(2.8)$ & $17(48.6)$ & $11(31.4)$ & $5(14.2)$ & $1(2.8)$ & $0(0.0)$ & $14(37.8)$ & $16(43.2)$ & 7 (18.9) & $0(0.0)$ \\
\hline
\end{tabular}

$\mathrm{N}=72,{ }^{a}$ reside less than $2 \mathrm{~km}$ from landfill, ${ }^{b}$ reside more than $2 \mathrm{~km}$ from landfill, *significant at $p<0.05$ 
Meanwhile, majority of the children in the unexposed group never suffered coughing with flu ( $\mathrm{N}=22$ ) and asphyxiate (coughing and flu) $(\mathrm{N}=27)$. Once in a week, they have experienced symptoms of coughing with flu $(\mathrm{N}=14)$ and asphyxiate (coughing without flu) $(\mathrm{N}=14)$ and once in a month they have experienced symptom of asphyxiate (coughing without flu) $(\mathrm{N}=16)$. A small number of the children in this group have coughing with flu $(\mathrm{N}=2)$ and coughing without flu $(\mathrm{N}=1)$ in everyday of their life. The Mann Whitney-U test shows that there was no significant difference of the frequency of these symptoms between exposed and unexposed children $(p>0.05)$.

\subsection{Relationship between $\mathrm{PM}_{10}$ and IL-6 with Health Symptoms}

Table 5 shows the relationship between $\mathrm{PM}_{10}$ concentration in air and IL-6 with health symptoms of children. Results of this study indicate that there was no significant relationship between $\mathrm{PM}_{10}$ concentrations and associated health symptoms except for coughing with phlegm among exposed children $(R=3.90, p=$ 0.054). For the exposed group, symptoms of coughing with and without flu, asphyxiate (coughing without flu), wheezing with flu and wheezing during daytime and night were the variables that have positive relationship with $\mathrm{PM}_{10}$ concentration in the air although not significant. The remaining symptoms had a negative relationship with $\mathrm{PM}_{10}$ concentration in the air. For the unexposed group, symptoms of wheezing after doing sports, runny nose and sneezing were the variables that have positive relationship with $\mathrm{PM}_{10}$ concentration in the air although not significant. The rest symptoms were indicated as negative relationship with $\mathrm{PM}_{10}$ concentration in the air.

As for IL-6 in saliva, results show no significant relationship with health symptoms except for coughing without flu among unexposed children $(r$ value $=-0.334, p=0.046)$. For the exposed group, symptoms of coughing with and without flu, sneezing and watery eye were the variables that have positive relationship with IL-6 in saliva although not significant. The remaining symptoms gave a negative relationship. For the unexposed group, symptoms of coughing with flu and Asphyxiate (coughing but without flu) were the variables that have positive relationship with IL-6 in saliva although not significant. The remaining symptoms gave a negative relationship.

\subsection{Relationship between Smoking Behavior and Respiratory Symptoms}

Table 6 shows the relationship between smoking behavior of the family and health respiratory symptoms among exposed and unexposed group. For the exposed group, there was a significant relationship between smoking behavior of the father in the family to the symptom of coughing with flu $\left(X^{2}=4.533\right.$ at $p=$ $0.033)$ and asphyxiate (coughing and flu) $\left(X^{2}=\right.$ 5.57 at $p=0.018$ ). Smoking among other family members has significant relationship with wheezing with flu at $X^{2}=7.978$ and $p=0.005$. As for the unexposed group, there was a significant relationship between smoking behavior of the father in the family to the symptom of coughing without flu at $X^{2}=5.786$ and $p=0.016$. Other symptoms were not correlated to the smoking habit in this study.

\section{DISCUSSION}

A total number of 72 children who lives in Pajam, Nilai, Negeri Sembilan were involved in this study. The majority of the respondents for both exposed and unexposed groups are Malays $(96 \%)$ and the rest are Indian. The ages of the respondents ranged between 8 to 12 years old. The majority of the exposed respondent aged between10 years old and 12 years old in unexposed group. There was significant difference of age between exposed and unexposed groups $(p<0.005)$. In terms of parental education, the majority of parents from exposed group have educational background up to diploma level while for the unexposed group, majority of the parents are having higher secondary level of education. The majority of the parents for both groups had full time employment with monthly income more than RM 3,000.

The majority of the respondents in both groups lived at their current address for 6 to 10 years range. There are 9 families from the exposed group lived more than 10 years in the areas. According to Corrêa, (2011), living in the landfill area was associated with the presence of respiratory symptoms in children aged below 13 years [10]. The duration of residency within the landfill area may increase the possibilities of being exposed with the particulates from the landfill. There was no significant difference of the residence duration between exposed and unexposed group in this study as shown in the Table 1. 
Living with pets factors also had been into account in this study as it is one of the confounding factors that can produce respiratory symptoms among children. National Institute of Health of United States (2013), indicates that living with pets was identified as risk factors to respiratory inflammation due to animal's allergen. These allergens are presented in dander, saliva, urine and others secretion, and their presence in air may be inhaled by human [14]. Once the allergens are inhaled into the lung, allergic symptoms result and lead to the respiratory problems. Inflammation of respiratory system may also cause excretion of IL-6. The majority of the respondents from both groups were not living with pets. There was no significant difference of having pets between exposed and unexposed group ( $p>0.05)$.

Smoking behavior of the family members were taken into account as one of the factor that influences Interleukin-6 (IL-6) excretion in this study. Exposure to tobacco smoke will impair the lung growth and caused respiratory inflammation which will be detected through IL-6 excretion. Children who are exposed to tobacco smoke are more likely to have asthma and other respiratory problems [15]. Table 1 shows the frequency of smoking behavior among the family members of the children. The data reveals that majority of the family members from both groups are nonsmoker. It also shows that there was no significant difference of smoking behavior among family members between exposed and unexposed group.

The Mean \pm SD of $\mathrm{PM}_{10}$ for exposed group (children who lives less than $2 \mathrm{~km}$ from landfill) was higher $\left(152.31 \pm 31.07 \mu \mathrm{g} / \mathrm{m}^{3}\right)$ than the unexposed group living more than $2 \mathrm{~km}$ from landfill $\left(87.77 \pm 30.77 \mu \mathrm{g} / \mathrm{m}^{3}\right)$. There are many potential reasons for this result. One of the possible reasons is the distance from landfill. High particulate matter was possibly comes from this landfill together with other sources such as from the traffic, the construction area as well as the industries. As the distance of the residence increases, the particulates exposure becomes less. This result corresponds to the conclusion from the World Health Organization (WHO) report that any potential exposure is likely limited to one to two kilometers from the site by air pathway [16]. According to Health Protection Agency (HPA) (2011), people who live for many years in area with high particle levels have been associated with problem such as reduced lung function and other respiratory problems [7]. Table 2 shows there was a significant difference between inhalation exposure of PM10 among exposed and unexposed children $(p<0.05)$.

Table 5. Analytical statistic of $\mathrm{PM}_{10}$ concentration with associated health related symptoms along with spearman's rank correlation $(p=0.05)$

\begin{tabular}{|c|c|c|c|c|}
\hline \multirow[t]{3}{*}{ Health symptoms } & \multicolumn{2}{|c|}{$\mathrm{PM}_{10}$} & \multicolumn{2}{|c|}{$\begin{array}{c}\text { IL-6 } \\
-\end{array}$} \\
\hline & $\begin{array}{l}\text { Exposed } \\
\operatorname{group}^{\mathrm{a}}(\mathrm{N}=35)\end{array}$ & $\begin{array}{l}\text { Unexposed } \\
\text { group }^{\text {b }}(\mathrm{N}=37)\end{array}$ & $\begin{array}{l}\text { Exposed group }^{\mathrm{a}} \\
(\mathrm{N}=35)\end{array}$ & $\begin{array}{l}\text { Unexposed } \\
\text { group }^{\mathrm{b}}(\mathrm{N}=37)\end{array}$ \\
\hline & $R$ value & $R$ value & $R$ value & $R$ value \\
\hline Coughing with flu & .059 & -.257 & 0.009 & .036 \\
\hline Coughing without flu & .103 & -.169 & .116 & $-.334^{*}$ \\
\hline $\begin{array}{l}\text { Asphyxiate (coughing } \\
\text { and flu) }\end{array}$ & -.083 & -.047 & -.038 & -.020 \\
\hline $\begin{array}{l}\text { Asphyxiate (coughing but } \\
\text { without flu) }\end{array}$ & .070 & -.191 & .032 & .102 \\
\hline Wheezing with flu & .169 & -.191 & -.013 & -.266 \\
\hline $\begin{array}{l}\text { Wheezing during day } \\
\text { time }\end{array}$ & .167 & 0 & -.136 & 0 \\
\hline Wheezing during night & .093 & 0 & -.015 & 0 \\
\hline Wheezing after sports & 0 & .151 & 0 & 0 \\
\hline Runny nose & -.105 & .138 & -.045 & -.016 \\
\hline Sneezing & -.225 & .102 & .30 & -.256 \\
\hline Watery eye & -.057 & 0 & .192 & -.270 \\
\hline Coughing with phlegm & $.390^{*}$ & 0 & 0 & \\
\hline Sore throat & -.209 & 0 & -.028 & \\
\hline Sinus & -.024 & -.208 & -.0 .10 & -.048 \\
\hline
\end{tabular}


Table 6. Relationship between smoking behavior of the family and health respiratory symptoms among exposed and unexposed groups along with chi-square test

\begin{tabular}{|c|c|c|c|c|c|c|c|}
\hline \multirow[t]{4}{*}{ Symptoms } & \multicolumn{3}{|c|}{ Exposed group $^{\mathrm{a}}(\mathrm{N}=35)$} & \multicolumn{4}{|c|}{ Unexposed group $^{\mathrm{b}}(\mathrm{N}=37)$} \\
\hline & \multicolumn{2}{|c|}{ Father } & \multirow{3}{*}{$\begin{array}{l}\text { Smoker among } \\
\text { other family member }\end{array}$} & \multicolumn{2}{|c|}{ Father } & \multirow{2}{*}{$\begin{array}{c}\text { Mother } \\
\text { Social smoker }\end{array}$} & \multirow{2}{*}{$\begin{array}{l}\text { Smoker among } \\
\text { other family } \\
\text { member }\end{array}$} \\
\hline & $\begin{array}{l}\text { Regular } \\
\text { smoker }\end{array}$ & Social smoker & & $\begin{array}{l}\text { Regular } \\
\text { smoker }\end{array}$ & Social smoker & & \\
\hline & \multicolumn{2}{|r|}{$\mathrm{x}^{2}(p$ value $)$} & & \multicolumn{4}{|c|}{$\mathrm{x}^{2}(p$ value $)$} \\
\hline Coughing with flu & $.180(.671)$ & $4.53(.033)^{*}$ & $1.030(.310)$ & $.068(.795)$ & $1.403(.236)$ & - & $.082(.774)$ \\
\hline $\begin{array}{l}\text { Coughing without } \\
\text { flu }\end{array}$ & $.029(.865)$ & $2.60(.107)$ & $.589(.443)$ & $5.786\left(.016^{\star}\right)$ & $.000(1.000)$ & - & $.232(.630)$ \\
\hline $\begin{array}{l}\text { Asphyxiate } \\
\text { (coughing and flu) }\end{array}$ & $5.57(.018)^{*}$ & $.383(.536)$ & $.178(.673)$ & $.027(.869)$ & $.065(.799)$ & $.597(.440)$ & $1.728(.187)$ \\
\hline $\begin{array}{l}\text { Asphyxiate } \\
\text { (coughing but } \\
\text { without flu) }\end{array}$ & $.972(.324)$ & $.972(.324)$ & $.172(.679)$ & $.284(.594)$ & $.381(.537)$ & $.100(.752)$ & $.161(.689)$ \\
\hline Wheezing with flu & $.012(.914)$ & $.753(.386)$ & $7.978(.005)^{\star}$ & $.284(.594)$ & $.381(.537)$ & $.100(.752)$ & $.161(.689)$ \\
\hline $\begin{array}{l}\text { Wheezing during } \\
\text { day time }\end{array}$ & $.305(.581)$ & $.172(.679)$ & $.030(.862)$ & - & - & - & - \\
\hline $\begin{array}{l}\text { Wheezing during } \\
\text { night }\end{array}$ & $.972(.324)$ & $.547(.460)$ & $.097(.756)$ & - & - & - & - \\
\hline $\begin{array}{l}\text { Wheezing after } \\
\text { sports }\end{array}$ & - & - & - & $.294(.588)$ & $2.674(.102)$ & $.103(.748)$ & $.166(.684)$ \\
\hline Runny nose & $.422(.810)$ & $2.443(.295)$ & $.429(.807)$ & $.596(.742)$ & $.729(.694)$ & $5.474(.065)$ & $2.141(.343)$ \\
\hline Sneezing & $1.330(.514)$ & $.849(.654)$ & - & $.246(.884)$ & $.711(.701)$ & $4.306(.116)$ & - \\
\hline Watery eyes & $.058(.972)$ & $.849(.654)$ & $.387(.824)$ & $3.631(.163)$ & - & - & - \\
\hline Sore throat & $.641(.726)$ & $1.589(.452)$ & $.589(.745)$ & - & - & - & - \\
\hline Sinus & $.026(.872)$ & $.305(.581)$ & $.147(.701)$ & $.580(.446)$ & $1.916(.166)$ & $.705(.401)$ & $2.407(.121)$ \\
\hline
\end{tabular}


The concentration of Interleukin-6 (IL-6) indicates the respiratory inflammation suffered by the respondents. IL-6was chosen as bio-indicator in this study as it is a multi-functional cytokine that regulates immune responses, acute phase reactions and hematopoiesis and may play a central role in host defense mechanisms. IL-6 is usually not produced constitutively by normal cells, but its expression is readily induced by a variety of cytokines, lipopolysaccharide or viral infections. Based on the descriptive statistic of IL-6concentration $(\mathrm{pg} / \mathrm{ml})$ in saliva samples of exposed group and unexposed group using Mann Whitney-U test, there was no significant difference between IL-6 concentration levels among these two groups. The mean \pm SD value of IL-6 for exposed group was slightly higher $(6.340 \pm 1.946 \mathrm{pg} / \mathrm{ml})$ than the unexposed group $(5.773 \pm 1.076 \mathrm{pg} / \mathrm{ml})$. High IL-6 concentration value could be contributed by various factors such as high exposure to particulates due to living near to landfill sites.

A study by Nascimento [17] reveals that there was a correlation between $\mathrm{PM}_{10}$ concentration and the number of hospital admission. Numbers of hospital admissions are always referred to the number of cases, disease or infection suffered by people due to certain exposure. In this study, health related problems or symptoms that mainly experienced by the children were coughing with and without flu, asphyxiate, wheezing during day time and night, wheezing during flu, runny nose, sneezing, watery eyes coughing with phlegm sore throat and sinus. These were all common symptoms suffered by those who were exposed to the particulates such as $\mathrm{PM}_{10}$. According to Table 3, watery eyes, coughing with phlegm and sore throat are among the symptoms that were significant difference between the two groups, the exposed and unexposed group. There are significant health symptoms from particulates exposure via inhalation of air due to living near to the municipal solid waste, the Pajam landfill.

Pajam landfill is a municipal solid waste landfill where they are practicing control tipping and daily soil cover. Particulates arise from these kind of activities hence disperse away to the nearby places, residence area for instance. Thus, the particulates increase the probability of getting respiratory disease as the residences inhale the pollutant in the air. This was proven by findings on Correa (2011) study, which determining whether living in a neighborhood with a landfill site that had been closed for 6 years previously was a risk factor for acute respiratory symptoms in children [10]. The study has found that a child who lives in the neighborhood had a $50 \%$ greater likelihood of having exhibited coughing or wheezing. The results of the study have shown that living in the landfill area was associated with the presence of respiratory symptoms in children aged below than 13 years [10].

Along with Table 5, using Spearman's rank correlation test, the IL- 6 concentrations were not correlated with most of the respiratory health symptoms except for coughing with phlegm among unexposed children. Some of the other symptoms only shows positive relationship between those 2 variables although not significantly. As IL-6 is involved in inflammatory responses and induction of acute phase protein, elevated serum levels of IL-6 should be determined.

\section{CONCLUSION}

This study has determined that there were positive relationships of health risks and $\mathrm{PM}_{10}$ exposure to the exposed group who are living near to the landfill site. However, further detailed and comprehensive research should be conducted to determine exact risks that the study respondents are facing from exposure of the particulates through inhalation. Moreover, local council should re-consider giving permission on development of housing area nearing to the landfill site.

\section{ETHICAL APPROVAL}

All authors hereby declare that all experiments have been examined and approved by the appropriate ethics committee and have therefore been performed in accordance with the ethical standards laid down in the Faculty of Medicine and Health Sciences, University Putra Malaysia.

\section{COMPETING INTERESTS}

Authors have declared that no competing interests exist.

\section{REFERENCES}

1. Ismail SNS, Manaf LA. The challenge of future landfill: A case study of Malaysia. Journal of Toxicology and Environmental Health Sciences. 2013;5(6):86-96.

2. Hoornweg $D$, Bhada-Tata $P$. What a waste: A global review of solid waste management. Urban Development and 
Local Government Unit, World Bank, Washington DC, USA; 2012.

3. Latifah AM, MohdArmi AB, Nurllyana MZ. Municipal solid waste management in Malaysia: Practices and challenges. Waste Management.2009;29:2902-2906.

4. Idris A, Inanc B, Hassan MN. Overview of waste disposal and landfills/dumps in Asian countries. Material Cycles and Waste Management in Asia. 2004;6:104110.

5. USEPA. Municipal solid waste; 2014. Available:http://www.epa.gov/epawaste/no nhaz/municipal/index.htm. Available online on $30^{\text {th }}$ September 2014.

6. Dalton P. Upper airway irritation, odour perception and health risk due to airborne chemicals. Toxic Lett. 2003;140-141:23948.

7. HPA (Health Protection Agency). Impact on Health of Emissions from Landfill Sites, London; 2011.

8. USEPA (United States Environmental Protection Agency). Particles Pollution and Your Health; 2003.

9. Carpenter DO, Ma J, Lessner L. Asthma and infectious respiratory disease in relation to residence near hazardous waste sites. Ann NY Acad Sci. 2008;1140:201208.

10. Corrêa CR, Abrahão CE, Carpintero MC, Anaruma FF. Landfills as risk factors for respiratory disease in children. $\mathrm{J}$ Pediatr (Rio J). 2011;87(4):319-24.
11. Gabay C, Kushner I. Acute-phase proteins and other systemic responses to inflammation. $\mathrm{N}$ Engl J Med. 1999;340:448-54.

12. Korostoff A, Reder L, Masood R, Sinha UK. The role of salivary cytokine biomarkers in tongue cancer invasion and mortality. Oral Oncology. 2011;47:282-287.

13. American Thoracic Society's Recommended Respiratory Disease Questionnaires for Use with Adults and Children in Epidemiological Research. The British Medical Research council, 20 Park crescent, London WIN 4AL, England; 1999.

14. Zainal Abidin E, Rasdi I, Ismail SNS, Semple S, Ayres JG. The relationship between air pollution and asthma in Malaysia schoolchildren. Air Qual Atmos Health; 2014.

15. Cook DG, Strachan DP. Summary of effects of parental smoking on the respiratory health of children and implications for research. Thorax. 1999;54;357-365

16. WHO. Methods of assessing risk to health from exposure to hazards released from waste landfills; 2000.

17. Nascimento LFC. Air pollution and cardiovascular hospital admissions in a medium-sized city in São Paulo State, Brazil. Braz J Med Biol Res. $2011 ; 44(7) ; 720-724$.

(0) 2015 Ismail et al.; This is an Open Access article distributed under the terms of the Creative Commons Attribution License (http://creativecommons.org/licenses/by/4.0), which permits unrestricted use, distribution, and reproduction in any medium, provided the original work is properly cited.

Peer-review history:

The peer review history for this paper can be accessed here: http://www.sciencedomain.org/review-history.php?iid=756\&id=31\&aid=6986 